\title{
Can telecollaboration contribute to the TPACK development of pre-service teachers?
}

\author{
M Camino Bueno-Alastuey \\ orcid.org/0000-0001-7027-5382 \\ Philology and Didactics of Languages, Public University of Navarre, Pamplona, Spain. \\ Izaskun Villarreal \\ orcid.org/0000-0002-8196-5968 \\ Philology and Didactics of Languages, Public University of Navarre, Pamplona, Spain.
}

\section{Soraya Garcia-Esteban}

orcid.org/0000-0002-7751-9877

Modern Philology, University of Alcala, Madrid, Spain.

\begin{abstract}
This study examines the suitability of telecollaboration practices to enhance ICT integration in Content and Language Integrated Learning (CLIL) based units by analysing the number and type of episodes related to students' TPACK produced in a telecollaboration whose aim was the design of a technology-enhanced CLIL unit. Results revealed a high number of episodes focusing on the domains and intersections of the TPACK framework, that PCK was the main focus of attention and provoked most of the suggestions for change in the unit and that telecollaboration promoted collaboration and evened participation. Consequently, telecollaboration showed a great potential for directing students' attention to their TPACK even though the scarcity of episodes focusing on the TPACK intersection also indicated there is ample room for more teacher training efforts to prepare pre-service teachers for technology integration.
\end{abstract}

Keywords: Pre-service teachers, TPACK, ICT, CLIL, telecollaboration.

\section{Introduction}

The rapid advancement and growth of technologies in recent years has brought about the need for pre-service teachers to be prepared to "adequately integrate information and 
communication technology (ICT) into their educational practice" (Tondeur, Aesaert, Pynoo, van Braak, Fraeyman, \& Erstad, 2016a, p. 1). National and international organizations have made efforts to aid in the appropriate preparation of pre-service teachers by establishing the competences and knowledge needed to effectively use ICT for educational purposes (INTEF, 2014; UNESCO, 2011).

Research on the effective integration of ICT for educational purposes has focused on case studies analysing the effectiveness of different proposals (Archambault \& Crippen, 2009; Niess, van Zee, \& Gillow-Wiles, 2010-11), as well as on studies proposing different tools to measure teachers' knowledge and ICT competences (Schmidt, Baran, Thompson, Mishra, Koehler, \& Shin, 2009; Tondeur et al., 2016a). The framework most extensively used by many of those studies to analyse and measure teachers' knowledge has been Mishra and Koehler's (2006) technological pedagogical content knowledge (TPACK) construct.

Although research has reported pre-service teachers growth of TPACK after instructional technology courses (Niess et al., 2010-11; Schmidt et al., 2009) and collaborative design experiences (Clark, Brown, \& Jandildinov, 2016; Koehler \& Mishra, 2009), authors in many different contexts (García-Valcárcel, Basilotta, \& López, 2014; Teo, 2009; Voogt \& McKenney, 2016) have pointed out that pre-service teachers still feel inadequately prepared to use ICT to their full potential. One of their main concerns is their lack of preparedness to use ICT for the development of transversal skills such as communicative competence or digital competence (European Commission, 2007).

Some reported lacks of initial teacher training programs are the scarce attention paid to design beyond lesson planning (McKenney, Kali, Markauskaite, \& Voogt, 2015), a lack of focus on instructional planning and implementation (Figg \& Jaipal, 2012) and very little hands-on experience with technologies used for collaborative purposes (Bueno-Alastuey \& García Esteban, 2016). These shortcomings could be overcome by using telecollaboration, which affords the opportunity to widen the scope of teachers' knowledge and to raise their awareness about ICT effective use by forcing them to collaborate with others and to justify their methodological and technological choices in their lesson plan designs. Therefore, the current study seeks to assess the opportunities telecollaboration practices offer to enhance ICT integration in CLIL based units.

\section{Literature background}




\section{Technological pedagogical content knowledge}

TPACK (see Fig. 1) was introduced by Koehler and Mishra (2005) by expanding Shulman's (1987) construct of pedagogical content knowledge (PCK) to include technological knowledge (TK) as situated within content (CK) and pedagogical knowledge (PK).

[Figure 1 near here]

TPACK is a theoretical framework for understanding the knowledge teachers require for effective technology integration. It assumes that teachers need more than "basic technological skills to be able to use technology to strengthen their pedagogical approach when providing subject-matter instruction to students with different interests and capabilities" (Heitink, Voogt, Verplanken, van Braak, \& Fisser, 2016, p. 71). Although the framework has been criticised due to its static view of teachers' knowledge (Graham, 2011; Olofson, Swallow \& Neumann, 2016), the substantial degree of overlapping between categories (Archambault \& Barnett, 2010), and because "the framework does not make explicit the connections among content, pedagogy and technology" (Angeli \& Valanides, 2009, p. 157), it is the framework most extensively used and accepted to explore the knowledge base needed for teaching and it highlights the connections between the three different types of knowledge. Furthermore, the framework has been successfully applied and validated to assess and bolster teachers' capacity for ICT integration (Archambault \& Crippen, 2009; Niess et al., 2010-11), to measure teachers' understanding of technology (Archambault, 2016; Phillips, 2016) and to evaluate teacher training experiences (Abbitt, 2011) and students' TPACK competence through digital portfolio ratings (Koehler, Greenhalgh, Rosenberg \& Keenan, 2017)

Teachers' use of ICT has been shown to improve after TPACK development efforts (Mishra \& Koehler, 2006) and research has demonstrated that teachers with appropriate TPACK skills tend to use technology to enrich or supplement the existing curriculum and to provide an enriched pedagogical approach (Ertmer, Ottenbreit-Leftwich, Sadik, Sendurer, \& Sendurer, 2012). However, research has also pointed out that there are very few courses or learning opportunities through which pre-service teachers can develop integrated knowledge (Voogt \& McKenney, 2016) and, thus, in-service teachers are still concerned regarding the 
suitability of ICT to enhance collaborative learning practices. Maximizing teacher training has been considered promising to eradicate those concerns (García-Valcárcel et al., 2014).

Teacher training efforts have already been made to increase TPACK awareness and the ICT competence of pre-service teachers. Most of them have used collaborative design in teams, which has revealed to offer ample opportunity for pre-service teacher learning (Agyei \& Voogt, 2012; Bueno-Alastuey \& García Esteban, 2016; Clark et al., 2016; Koehler, Mishra, \& Yahya, 2007). Notwithstanding this, studies highlight that some of the domains of the framework, namely TK and TCK, seemed to be not as developed as the others (GarcíaValcárcel et al., 2014). Consequently, there is ample room for further teacher training efforts directed to the development of those domains.

\section{Content and Language Integrated Learning}

In the last few decades the desire to improve the learning of foreign languages (FL) in the present multilingual Europe has led to a burgeoning of Content and Language Integrated Learning programmes (CLIL). CLIL has been used to give cover to a myriad of educational approaches aimed at teaching subject matter through a FL (Marsh, 2002). Furthermore, CLIL has also been reported to contribute to the development of some of the EU lifelong competences such as communication in the FL competence, the learning to learn competence, and the digital competence (European Commission, 2007; Marsh, 2002).

Just as the competences needed by teachers to be able to integrate ICT effectively have been determined, the professional competences of the CLIL teacher to impart different contents through the medium of an L2 have also been described. Ball, Kelly and Clegg (2015) proposed a three savoirs model in which they split those training demands into three frames: (1) savoir which comprises a more theoretical-type of knowledge as, for instance, teaching and learning theories, subject pedagogy, CLIL fundamentals, literacy and ICT skills; (2) savoir-faire which refers to the actual act of teaching and is divided into five components: plan, teach, assess, create a learning environment, and collaborate and finally, (3) savoir-être which refers to teachers' disposition and attitudes. ICT are overtly mentioned in the planning and teaching components of this frame, and, thus, any CLIL training program should also include the integration of ICT into the teaching of specific content areas, as acknowledged by the TPACK framework. 
Given the complex nature of combining CLIL and ICT knowledge to produce effective lessons, and the fact that research has illustrated the benefits of integrating TPACK in subject matter method courses (Hofer \& Owings-Swan, 2005; Jimoyiannis, 2010) and that beginning teachers prepared by programmes that teach how to integrate technology in content areas seemed best prepared (Tondeur, Pareja Roblin, Van Braak, Voogt, \& Prestridge, 2016b), it seems worth exploring how to create courses in which students are forced to integrate different domains of the TPACK framework to create a lesson plan.

Virtual group collaboration has been shown to provide multiple opportunities to develop students' different processes of knowledge building by enabling negotiation of meaning, reconceptualization of previous knowledge, general cognitive development and the creation of learning communities (Graham \& Misanchuk, 2004), and has emerged as the best approach to trace the development of the components of TPACK (Koehler et al., 2007).

Consequently, using telecollaboration in a training programme will allow pre-service teachers to reflect on the practical use of different communication tools and, thus, to improve their TPACK skills (Bueno-Alastuey \& Garcia Esteban, 2016).

\section{Telecollaboration}

Students today have grown up within a world of pervasive technologies (Duffy, 2008) and education is compelled to respond to technology and connectivity as a primary facilitator of information and knowledge (Pennock-Speck, 2013). It is not sufficient to use online learning and teaching technologies simply for the delivery of content to students; digital technology provides educators with different possibilities for engaging students in desirable practices such as collaborative content creation, peer assessment, and increase students' motivation for the acquisition of content and language (Garcia-Esteban, 2015).

Virtual collaboration - or telecollaboration-, which refers to the application of online communication tools to bring together learners in different locations with the aim of developing their base knowledge and competences through collaborative tasks and project work (Vinagre, 2016), has also been shown to be an appropriate approach to facilitate teacher training (Bueno-Alastuey \& Kleban, 2016; Clark et al., 2016; Dooly \& Sadler, 2013). As pointed out by Palloff and Pratt (2005), telecollaboration boosts learning outcomes, including the development of critical thinking skills, the co-creation of knowledge and meaning, 
reflection, and transformative learning while it "supports social interaction, dialogue, debate, and intercultural exchange" (Belz, 2005, p. 23).

Current studies on telecollaboration in FL teaching and learning have shown its potential to foster FL skills and awareness (Bueno-Alastuey, 2011, 2013; Polisca, 2011), develop higher order thinking skills (Von der Emde, Schneider, \& Kötter, 2001) or critical thinking (Zaragoza-Ninet, \& Clavel-Arroitia, 2010). Specifically, telecollaboration has been shown to contribute to the development of competences (Vinagre, 2016) and teacher trainees' TPACK (Archambault \& Crippen, 2009; Bueno-Alastuey \& Kleban, 2016). These authors encourage educators to enhance their teaching procedures using telecollaborative tools to raise awareness of the strengths, shortcomings, and development of subject matter teaching, and to enrich critical reflection on technology use (Clark et al., 2016). Further benefits of using telecollaboration with FL teacher trainees include the opportunity for 'exploratory' teaching practice (Guichon \& Hauck, 2011), 'experiential modelling' (Guichon, 2009; Hampel, 2009), and the development of multimodal communicative competence, multiliteracy, autonomy, and the teacher competences required for teaching with multimodal technologies (Fuchs, Hauck, \& Müller-Hartmann, 2012).

Despite all the aforementioned benefits, research exploring the use of telecollaboration for teacher training purposes remains limited and, thus, this study aims to contribute to the understanding of how telecollaboration can aid in the development of the different domains of the TPACK of teacher trainees (Bueno-Alastuey \& Garcia Esteban, 2016; Vinagre, 2016).

\section{Materials and method}

\section{The aim and design of the study}

This study was designed to analyse the opportunities telecollaboration might provide for preservice teachers' TPACK development and it is beyond its scope to measure actual gains in TPACK knowledge. Telecollaboration was deemed as the most suitable means of promoting both interaction and experiential learning about technology, as virtual exchanges have been said to bring about added pedagogical value (O'Dowd, 2013) and bridge the gap between theory and practice (Dooly \& Sadler, 2013). Telecollaboration tasks have been shown to enhance preservice teacher technopedagogical development by offering opportunities to experience the affordances of technology and to link their knowledge about existing 
technological possibilities and opportunities with experiential use and integration (Dooly \& Sadler, 2013). This experiential and authentic use of technologies is not possible in face-toface contexts, and has been considered by some authors as a facilitator of ICT integration in ways that are supportive of learning (Meskill, Anthony, Hilliker-Van Strander, Tseng \& You, 2006), of increased awareness on issues related to technopedagogical design and implementation (Bueno-Alastuey \& Kleban, 2016), and even a sine qua non condition for the future application of such tools and processes (Guichon \& Hauck, 2011). Additionally, experiential learning can contribute to the development of TPACK knowledge by engaging students in 'cognitive apprenticeship' which affords them the opportunity to be creators of knowledge by way of active collaboration and reflection (Collins, Brown \& Newman, 1989; Dickey, 2007a, 2007b; Hockly, 2000; Vasileiou \& Paraskeva, 2010).

Consequently, the telecollaboration aimed at encouraging students to reflect on their CLIL and technopedagogical knowledge, and to have experiential use of technological resources to be better prepared to overcome reported constraints of technology in their future practice (García-Valcárcel et al. 2014; Helm, 2015). Following the TPACK framework, which considers "that teaching is a highly complex activity that draws on many kinds of knowledge ... [and] is a complex cognitive skill occurring in an ill-structured, dynamic environment" (Mishra \& Koehler, 2006, p. 1020), three different factors were selected to analyse the impact of the telecollaboration:

a) Episodes in the telecollaboration related to i) technological knowledge (TK), ii) technological pedagogical knowledge (TPK), iii) pedagogical content knowledge (PCK), and iv) technological pedagogical content knowledge (TPACK).

b) Suggestions for improvement to the CLIL unit.

c) Characteristics of the telecollaboration (collaborative, levelled, or reflective).

\section{The participants}

The participants were two intact groups of pre-service teachers from the Public University of Navarre (UPNA) and the Cardenal Cisneros University Centre (CUCC, University of Alcalá) in Spain.

The UPNA group was comprised of 38 students, who were doing their final year in a Degree of either Primary or Early Childhood Education. The students were doing two specific subjects in English: CLIL, which had 60 hours contact time and 90 hours of personal work, 
and New Technologies applied to Language Learning, which had 30 hours contact time and 45 hours of personal work.

The CUCC group was comprised of 17 students, who were doing their final year in a Degree of Primary Education. The students were doing a subject in English called A practical approach to the English-speaking cultures, consisting of 48 hours contact time and 102 of personal work.

This study was designed so that students in the first group could integrate what they were learning in both subjects, and students in the second group could reflect on the process of creating an effective CLIL unit.

\section{The tasks and instruments}

The tasks were designed to be goal-oriented, to demand information exchange and to respond to students' needs (Long, 2015). The first task consisted in completing a questionnaire (Bentley, 2010) which targeted the foundational knowledge students had about CLIL. The questionnaire had ten questions including aspects such as the definition of CLIL, the role of active learning, authenticity, learning skills, the dimensions of CLIL, task design and cognitive skills. The questionnaire was filled individually first, then discussed in groups and then using telecollaboration.

For the second task, students had to analyse a CLIL unit created by a group in the other location and then discuss it with the authors of the unit. Students were asked to pay attention to how CLIL and Lower Order Thinking Skills (LOTs) and Higher Order Thinking Skills (HOTs) (derived from Bloom, 1956) were developed in the unit, how the progression of cognitive skills was established, and the appropriateness of ICT use. Additionally, students were asked to note down to provide suggestions for improvement in HOTs development and ICT integration. This reflective task would allow the preservice teachers "to critically examine their values, assumptions, theories and strategies that underlie their behavior and then take informed decisions in their teaching" (Dooly \& Sadler, 2013, p.8). After analysing the units, students carried out their second telecollaboration exchange, in which they provided the creators of the unit with information regarding all the aforementioned aspects.

The third and final task was a follow-up off-line written reflection task. This task was conceived as a post-task activity (Jauregi, 2015) with the aim of stimulating reflection upon the telecollaboration and its procedure. It was considered that the written individual 
contribution could further contribute to students' TPACK development through the process of awareness raising inherent to reflection tasks.

The instruments used to collect the data to be employed in our study were the transcriptions of the first and second telecollaborations, and the students' written reflections about the telecollaboration and the CLIL units.

\section{The procedure}

The students were divided into 9 groups in each location. Groups had three or four members each in the UPNA and two members in CUCC. The students were given the questionnaires and each of the group members prepared their own questionnaire for homework. The following session involved a discussion about their answers with the rest of the members of the group in the same location to reach an agreement on the answers.

In the following class, students connected with their partners from the other university and had a telecollaboration session using Skype and recorded their interactions with Debut Video Capture Software (version 2.05). During the exchange, they discussed their answers to the questionnaire and justified their choices. Once they finished, the recordings were stored.

After this session, each group in both of the locations created a CLIL unit following Coyle, Hood and Marsh's (2010) 4Cs framework on a topic of their choice. They were also compelled to integrate ICT in a meaningful way into their CLIL units, although they were free to choose the ICT tools that best suited their needs. Afterwards, they sent the unit to the corresponding group, who had to analyse the unit, in the other location. Finally, students had a second telecollaboration session to discuss their analysis of the units.

Once students had carried out the telecollaboration, they had to hand in a written reflection about the process of the telecollaboration they had carried out providing also a commentary within the reflection about their units and the way the units had improved by working with their partners.

\section{Data categorization and analysis}

The recordings were transcribed, and both the transcriptions and the reflections were analysed using content analysis as it "provides a systematic analysis of textual data" and a "replicable technique for compressing many words of text into fewer categories based on explicit rules of 
coding" (Stemler, 2001, p. 1). This technique allows for a variety of textual analyses and typically involves comparing, contrasting, and categorizing a set of data (Schwandt, 1997).

First the variables to be studied were decided, and a categorization employed in a previous pilot study (Bueno-Alastuey \& Garcia Esteban, 2016) was used to identify them in the transcriptions and the reflections. Secondly, the three coders coded four transcripts (two from first telecollaboration and two from the second telecollaboration) independently. The resulting coded transcripts were compared and all the differences in coding were discussed until a total intercoder agreement was reached. Finally, the remaining transcripts and reflections were distributed and coded. The three coders were in constant communication and when any of them had any uncertainty about specific codings, a meeting was arranged and those instances were discussed until agreement was reached. After all the transcripts and the reflections were coded, the data were introduced in Excel spreadsheets both to evaluate the usefulness of the experience and to identify relationships between the different variables.

As our purpose was to analyse the effect of the telecollaboration on technological knowledge and the subject to be learned was CLIL, which is in the intersection between pedagogy and content, we only coded episodes in which (1) technological, (2) technological pedagogical, (3) pedagogical content, and (4) technological pedagogical content knowledge was the focus of the episode. As it had been considered in a previous study (Bueno-Alastuey \& Garcia Esteban, 2016), an episode was defined as any event in the conversation when a student's attention was drawn towards one of the aspects mentioned above and episodes were identified and coded depending on the focus of the episode (following definitions provided by Schmidt et al., 2009, p. 125) into:

- Technological knowledge episodes (TK), which refer to episodes when the attention was focused on knowledge about technology, that is "knowledge about various technologies, ranging from low-tech technologies such as pencil and paper to digital technologies such as the Internet, digital video, interactive whiteboards, and software programs." Extract 1 below is an example of a TK episode.

\section{Extract 1:}

UPNA3: [No, pero no nos vemos no? Modo grabación de pantalla ... Iranzu... Iranzu ..] (No, but we don't see each other, no? Screen recording ....)

UPNA1: [Bea, el vuestro está grabando?

(Bea, is yours recording?) 
UPNA3: Is it recording?

Teacher: No, because it needs to be in ... Did they add you? ah, yes

UPNA3: here .. recording with this program

Teacher: I guess so .. yes, when you press the rec .. so it will be recorded ... it is being ... have you done it before?

UPNA3: No, never

Teacher: I guess so

UPNA3: You hope so]

UPNA1: Bea, can you see us?

- Pedagogical Content knowledge related episodes (PCK), which refer to episodes when the attention was focused on the methods and processes of teaching and includes knowledge in classroom management, assessment, lesson plan development, and student learning and on CLIL, which in our case was "knowledge about actual subject matter that is to be learned or taught" (Mishra \& Koehler, 2006, p. 1026). Extract 2 illustrates a PCK instance.

Extract 2:

UPNA2: maybe you use the level of understanding and the level of remembering but for example eh we think that you didn't use the creating the evaluating and the analyzing eh because we couldn't find that eh levels in your unit [sic]

UPNA1: what do you think? Hahaha

- Technological pedagogical knowledge episodes (TPK), which refer to those occasions in which attention focused on "the knowledge of how various technologies can be used in teaching, and to understanding how using technology may change the way teachers teach". Extract 3 shows evidence of TPK.

Extract 3:

CUCC. We have taken video ...

UPNA: what have you done with the video?

CUCC. We had to include videos in this unit

UPNA: But I really liked this idea to listen to music while they are doing whatever in class I think it's very positive so 
- Technological pedagogical content knowledge episodes (TPACK), which refer to those instances in which attention is focused on the knowledge of how various technologies can be used in teaching a particular subject "The knowledge required by teachers for integrating technology into their teaching in any content area ... teaching content using appropriate pedagogical methods and technologies." Extracts 4 and 5 are examples of TPACK.

Extract 4:

UPNA: imagine $\mathrm{xxx}$ introduce a youtube canal channel eh where where different people of different countries eh are playing these songs this song and another songs eh so what we want with this unit is to to create to educate in values in values

UPNA: and because of that our final project is to create

Extract 5:

UPNA: yes do you know the program hot hot potatoes?

CUCC: eh we know it but mmh we work with it in in the first course

UPNA: ah yes but for example eh we think that is a good option eh to put to put in your lesson plan because you can prepare some some activities about vocabulary with that programs and eh

UPNA: and they can experiment and use that technologies and yes they can do

After the episodes were counted, any suggestions for improvement of the CLIL units the students had provided were also identified and coded. Extracts 6 and 7 illustrate some of these suggestions.

Extract 6: TPACK suggestion

UPNA: In order to add some high order thinking skills activity we said changing the Power Point activity and instead of giving the information to the students, we think that they should choose a topic they really like from any topic they like, and then they have to look for the information, they have to look for it and then they have to explain it to the others in a brief way but at least they have 
to think about where do they have to look for the information and then they have to collect it and explain it

\section{Extract 7:}

CUCC: ...? You use a video

UPNA: No, we didn't use a video

CUCC: No, but it's an advice for you

UPNA. Ahhh!!! Ok.

UPNA: Yes, it's a very nice advice because sometimes it was a bit confusing when we were making the movements that they were not ... they were a bit confused so yes thanks for the advice

Secondly, three characteristics of the telecollaboration which could involve improvement or create better conditions for learning were analysed: (1) whether there was collaboration or only cooperation when reporting their ratings, but without discussion in the exchange, (2) whether all participants intervened or the discussion was dominated by some members of the groups and (3) whether the telecollaboration included some kind of reflection or it was just informative.

\section{Results}

\section{Episodes}

As can be seen in Table 1, there were a high number of episodes of all types of knowledge in the three tasks (326). PCK episodes had the highest incidence (137 [58.3\%]), followed by TK episodes (50 [21.3\%]) and TPK episodes (38 [16.2\%]), while TPACK episodes were the least frequent $(10[4.3 \%])$.

Regarding the tasks, the highest number of episodes took place in Telecollaboration 2 (TEL2) (136 [41,7\%]), closely followed by the Reflection (REFL) (115 [35.3\%]), while Telecollaboration 1 (TEL1) triggered notably fewer instances (75 [23\%]).

Both in TEL1 and TEL2, the most frequent type of episode was PCK (50 [66.7\%)] and $60[44.1 \%]$ respectively), followed by TK (20 [26.7\%] and 46 [33.8\%]). TPK was occasionally the focus of episodes in TEL2 (22 [16.2\%]) but rarely in TEL1 (4 [5.3\%]). 
Finally, TPACK was hardly ever the focus of students' attention in any of the oral exchanges $(1[1.3 \%]$ in TEL1 and $8[5.9 \%]$ in TEL2).

Nearly the same pattern was observed in students' written reflections (REFL). PCK episodes were the most common (95 [82.3\%]). However, TPK episodes were the second most common type (16 [13.9\%]) while both TK and TPACK episodes were rare (2 [1.7\%]).

Table 1: Number and percentage of episodes in TEL1, TEL2 and REFL

\begin{tabular}{llllll}
\hline TASK & TK & TPK & PCK & TPACK & TOTAL \\
TEL1 & 20 & 4 & 50 & 1 & 75 \\
& $26.7 \%$ & $5.3 \%$ & $66.7 \%$ & $1.3 \%$ & $23 \%$ \\
TEL2 & 46 & 22 & 60 & 8 & 136 \\
& $33.8 \%$ & $16.2 \%$ & $44.1 \%$ & $5.9 \%$ & $41.7 \%$ \\
REFL & 2 & 16 & 95 & 2 & 115 \\
& $1.7 \%$ & $13.9 \%$ & $82.6 \%$ & $1.7 \%$ & $35.3 \%$ \\
TOTAL & 50 & 38 & 137 & 10 & 326 \\
& $21.3 \%$ & $16.2 \%$ & $58.3 \%$ & $4.3 \%$ & $100 \%$ \\
\hline
\end{tabular}

\section{Suggestions for improvement}

Table 2 shows that REFL was the task that triggered the highest number of suggestions for improvement (43 [63.2\%]), followed by TEL2, which generated half as many instances (22 [32.3\%]) and TEL1 (3 [4.4\%]).

As for the type of suggestions produced, students mostly produced PCK-type suggestions (46 [67.7\%]), followed at a distance by TPK-type ones (15 [22.1\%]), while TK and TPACK-type suggestions were rare (3 [4, 4\%] and 4 [5.9\%], respectively).

REFL was also the task that triggered the highest number of each type of suggestion (30 PCK, 11 TPK and 2 TPACK), except for TK suggestions which only happened in TEL2 (3 instances). Fewer instances were generated in TEL2 (13 PCK, 4 TPK, and 2 TPACK) and TEL1 (3 PCK).

As for the focus of the suggestions, PCK suggestions frequently indicated the need to target more HOT skills, to increase scaffolding or collaborative practices, or brought activity design into the spotlight. Participants showed knowledge about the underpinnings of CLIL and suggested improvements in line with its principles.

Table 2: Suggestions and type of suggestions in TEL1, TEL2 and REFL

\begin{tabular}{lllll}
\hline Number of suggestions & TK & TPK & PCK & TPACK \\
\hline
\end{tabular}




\begin{tabular}{llllll}
\hline TEL1 & 3 & & & 3 & \\
TEL2 & 22 & 3 & 4 & 13 & 2 \\
REFL & 43 & & 11 & 30 & 2 \\
TOTAL & 68 & 3 & 15 & 46 & 4 \\
& & $4.4 \%$ & $22.1 \%$ & $67.7 \%$ & $5.9 \%$ \\
\hline
\end{tabular}

\section{Characteristics of the telecollaborative exchange}

Regarding the characteristics of the exchanges, collaboration had happened in most of the groups in both telecollaborations (80\% in TEL1 and $85.7 \%$ in TEL2). In addition, the same number of groups had also reflected about the task and the design of the unit. Furthermore, all members seemed to have participated in similar proportions in most of the groups. It seems, therefore, that the nature of the task was not relevant for participation and collaboration and both assignments generated similar types of interactions from the groups.

Table 3: Collaboration, mean of participants, dominance level and existence of reflection

\begin{tabular}{lllll}
\hline \multirow{2}{*}{ TEL1 } & Collaboration & Participants mean & Levelled & Reflection \\
& $8 / 5$ & $\mathrm{M}=5.4$ & $4 / 5$ & $4 / 5$ \\
TEL2 & $60 \%$ & & $80 \%$ & $80 \%$ \\
& $6 / 7$ & $\mathrm{M}=4.86$ & $5 / 7$ & $6 / 7$ \\
\hline
\end{tabular}

\section{Discussion and conclusions}

The results of our study show that telecollaboration projects can boost knowledge exchange and collaborative practices among pre-service teachers. The high number of episodes found indicated that virtual exchanges focused on lesson planning offer students ample opportunities to focus on their TPACK, and to develop their knowledge of the various TPACK domains. This has been shown to result in enhanced teaching expertise (BuenoAlastuey \& Garcia Esteban, 2016; Dooley \& Sadler, 2013). Furthermore, these endeavours increase their opportunities to work with different technologies, which might allow students to overcome the lack of enough practice with different ICT reported as one of the greatest deficiencies of teacher training programs (García-Valcárcel \& Martín del Pozo, 2016). The need to use technology and the constraints associated to its use can help teacher trainees discover ICT affordances and new ways to work and use them, which is something not possible in face-to-face contexts where ICT use is not a requirement. 
The type of episodes attested show that students predominantly focused on and showed PCK across tasks (TEL1 66.7\%, TEL2 44.1\%, REFL 82.6\%). This reveals that pre-service teachers still feel more knowledgeable in domains related to pedagogy or content or their intersection and it corroborates previous findings (Boschman, McKenney \& Voogt, 2015; Koh, Chai \& Tay, 2014) indicating that practical concerns seemed to dominate collaborative design discussions.

The collaboration with distant partners forced students to focus their attention on TK, which was specifically targeted as they were doing a course on instructional technology. The fact that the tasks forced them to use technology seemed to have had some impact on their TPACK knowledge construction which would not have been possible in face-to-face settings. Nevertheless, the scarcity of TPK and TPACK instances suggests that integration of TK knowledge into TPK and TPACK might need more time or more opportunities to evolve, and that other type of tasks should also be provided.

These findings support previous studies (Koehler et al., 2007) which have attested that teachers seem to develop first the individual domains of the framework and later the intersections. Similar results had been attested among in-service teachers (Roig, Mengual, \& Quinto, 2015), and the authors urged to move from mere exposure to existing technological resources to their application in pursuit of successful teaching and learning experiences.

The number and type of suggestions also paralleled the type of knowledge students had focused on. The overwhelming majority dealt with PCK and confirm the lack of focus on technological aspects and the intersections in the comments about their teaching proposals. These results add more support to our findings about telecollaboration practices, as well as to previous research mentioning the need to provide more opportunities for TPACK development for pre-service teachers in different contexts (García-Valcárcel et al, 2014; García-Valcárcel \& Martín del Pozo, 2016) and confirm the lack of proficiency in technology integration of teacher trainees in their last year of the degree. Therefore, a call for more initiatives to improve prospective teachers' TPACK so that they can apply it in their future teaching and "think about technology use in an integrated way" (Heitink et al., 2016, p. 81) is made.

Notwithstanding, the type of tasks proposed corroborated that the dynamic nature of knowledge is heavily influenced by the context of application (Abbitt, 2011) and, thus, affected the TPACK displayed by the participants. The behaviour of the groups varied across tasks: the lack of episodes of TK, TPK and TPACK in TEL1 might be a consequence of the 
type of task proposed. Students had to discuss about the underpinnings of CLIL and, thus, technological issues were not directly targeted. TEL2 was the task that generated the highest number and type of episodes as students commented on technology use and CLIL strategies. Finally, REFL was the task that seemed to engage students into deepest involvement and discussion over the units as observed by the high number and variety of suggestions for improvement raised. From these results, we can conclude that task design, which has been reported to influence the type of learning developed (O’Dowd \& Waire, 2009), should be carefully considered to allow pre-service teachers to display their full potential An improvement over the tasks investigated would be the creation of a final joint CLIL unit as this would encourage a move from simple exchange or information comparison to more indepth discussion on crucial aspects such as the underlying learning theory, the pedagogical decisions as well as the best type of ICT integration. This would follow Heitink et al.'s (2016) recommendation regarding the possible improvement of teacher's effective use of technology "if they become better able to articulate the reasoning behind the use of technology in their teaching, [sharing] this reasoning with colleagues" (p. 82). A joint product would, therefore, allow pre-service teachers to display their TPACK knowledge at its best, a direction worth pursuing for future research.

Another important finding relates to the benefits of telecollaboration to even the participation of all members (Kaye, 1989) and to increase collaboration. Our results show that $80 \%$ of the groups collaborated and that in $80 \%$ of the instances such collaboration was equally distributed among the participants. This highlights the importance of telecollaborative practices to increase critical thinking and to develop collaboration skills (Schmid, \& Hegelheimer, 2014). Furthermore, this kind of telecollaborative projects which force students to work with partners in another location seem to be similar to working contexts and might help to develop competences that they will need "when they enter the labour market whilst still in education" (Vinagre, 2016, p. 181).

Increasing teacher knowledge is a complex embryonic domain. As Hofer and Grandgenett (2012) explained "TPACK development within a teacher education program is no doubt a complex endeavour where students may need to experience a range of learning opportunities to maximize their growth" (p. 101). Underlying this intricacy we find three key components: knowledge of content, knowledge of pedagogy, and knowledge of technology. The complexity of their integration comes from an appreciation of the rich connections among these constructs and the ways in which these can be developed in a dynamic 
telecollaborative context. In using telecollaboration and the CLIL approach within a TPACK framework, this study has pursued to provide such view so as to improve pre-service teacher competences and knowledge in tertiary education, and to try to facilitate teacher educators' experimentation with (domain-specific) technologies (Voogt \& McKenney, 2016).

\section{References}

Abbitt, J.T. (2011). Measuring Technological Pedagogical Content Knowledge in Preservice Teacher education. Journal of Research on Technology in Education, 43(4), 281-300.

Agyei, D. D., \& Voogt, J. (2012). Developing Technological Pedagogical Content Knowledge in Pre-Service Mathematics Teachers through Collaborative Design. Australasian Journal of Educational Technology, 28(4), 547-564.

Angeli, C., \& Valanides, N. (2009). Epistemological and methodological issues for the conceptualization, development, and assessment of ICT-TPCK: Advances in technological pedagogical content knowledge (TPCK). Computers \& Education, 52(1), $154-168$

Archambault, L. (2016). Exploring the use of qualitative methods to examine TPACK. In M.C, Herring, M.J. Koehler, and P. Mishra (Eds.), Handbook of Technological Pedagogical Content Knowledge (TPACK) for Educators (pp. 65 -86). New York: Routledge.

Archambault, L. M., \& Barnett, J. H. (2010). Revisiting technological pedagogical content knowledge: Exploring the TPACK framework. Computers and Education, 55(4), 16561662. DOI: 10.1016/j.compedu.2010.07.009

Archambault, L., \& Crippen, K. (2009). Examining TPACK among K-12 Online Distance Educators in the United States. Contemporary Issues in Technology and Teacher Education, 9(1), 71-88.

Ball, P., Kelly, K., \& Clegg, J. (2015). Putting CLIL into Practice. Oxford, UK: Oxford University Press.

Belz, J. A. (2005). Intercultural Questioning, Discovery, and Tension in Internet-Mediated Language Learning Partnerships. Language and Intercultural Communication, 1, 3-39.

Bentley, K. (2010). The TKT course: CLIL Module. Cambridge (UK): Cambridge University Press. 
Bloom, B. S. (1956). A Taxonomy of Educational Objectives: The Classification of Educational Goals; Handbook I: Cognitive Domain. New York: Longmans, Green.

Boschman, F., Mckenney, S., \& Voogt, J. (2015). Exploring Teachers' Use of TPACK in Design Talk: The Collaborative Design of Technology-Rich Early Literacy Activities. Computers \& Education, 82, 250-262.

Bueno-Alastuey, M.C. (2011) Perceived benefits and drawbacks of synchronous voice-based computer-mediated communication in the foreign language classroom. Computer Assisted Language Learning, 24 (5), 419 - 432.

Bueno-Alastuey, M.C. (2013) Interactional feedback in Synchronous Voice-based Computer Mediated Communication: Effect of dyad, System, 41 (3), 543-559.

Bueno-Alastuey, M.C. \& García Esteban, S. (2016). Telecollaboration to improve CLIL and TPACK Knowledge: aid or hindrance? Estudios Sobre Educación (ESE), 31, 117-138.

Bueno-Alastuey, MC \& Kleban, M. (2016). Matching linguistic and pedagogical objectives in a telecollaboration project: a case study. Computer Assisted Language Learning, 29 (1), $148-168$

Clark, J. S., Brown, J. S., \& Jandildinov, M. (2016). Enriching preservice teachers' critical reflection through an international videoconference discussion. Technology, Pedagogy and Education, 24(4), 431 - 450.

Collins, A., Brown, J. S., \& Newman, S. E. (1989). Cognitive apprenticeship: Teaching the crafts of reading, writing, and mathematics. In L.B. Resnick (Ed.), Knowing, learning, and instruction: Essays in honor of Robert Glaser (pp. 453-494). Hillsdale, NJ: Lawrence Erlbaum.

Coyle, D., Hood, P., \& Marsh, D. (2010). CLIL. Cambridge: Cambridge University Press.

Dickey, M. D. (2007a). Barriers and enablers in integrating cognitive apprenticeship methods in a Webbased educational technology course for K-12 (primary and secondary) teacher education. ALT-J, 15(2), 119-130.

Dickey, M. D. (2007b). Integrating cognitive apprenticeship methods in a web-based educational technology course for P-12 teacher education. Computers \& Education, 51, $506-518$.

Dooly, M., \& Sadler, R. (2013). Filling in the Gap: Linking Theory and Practice through Telecollaboration in Teacher Education, ReCALL, 25(1), 4-29.

Duffy, P. (2008). Engaging the YouTube Google-eyed Generation: Strategies for Using Web 2.0 in Teaching and Learning. Electronic Journal of e-Learning, 6(2), 119-129. 
Ertmer, P.A., Ottenbreit-Leftwich, A.T., Sadik, O., Sendurer, E., \& Sendurer, P. (2012). Teacher Beliefs and Technology Integration Practices: A Critical Relationship. Computers \& Education, 59, 423-435.

European Commission. (2007). Key competences for lifelong learning. European Framework of Reference. Luxembourg: European Commission.

Figg, C., \& Jaipal, K. (2012). TPACK-in-Practice: Developing 21st Century Teacher Knowledge. In P. Resta (Ed.), Proceedings of Society for Information Technology \& Teacher Education International Conference 2012 (pp. 4683-4689). Chesapeake, VA: AACE.

Fuchs, C., Hauck, M., \& Müller-Hartmann, A. (2012). Promoting Learner Autonomy through Multiliteracy Skills Development in Cross-Institutional Exchanges. Language Learning \& Technology, 16(3), 82-102.

Garcia-Esteban (2015). Teaching CLIL with digital literacies, Verbeia, 0, 47-63.

García-Valcárcel, A., Basilotta, V., \& López, C. (2014). Las TIC en el aprendizaje colaborativo en el aula de Primaria y Secundaria [ICT in Collaborative Learning in the Classrooms of Primary and Secondary Education]. Comunicar, 42, 65-74.

García-Valcárcel, A., \& Martín del Pozo, M. (2016). ¿ Se sienten preparados los graduados en maestro de primaria para afrontar la profesión docente? Bordón. Revista de pedagogía, $68(2), 69-84$.

Graham, C. R. (2011). Theoretical considerations for understanding technological pedagogical content knowledge (TPACK). Computers \& Education, 57(3), 1953-1960.

Graham, C.R., \& Misanchuk, M. (2004). Computer-Mediated Learning Groups: Benefits and Challenges to Using Group work in Online Learning Environments. In Roberts, T. (Ed.), Online Collaborative Learning: Theory and Practice (pp.181-214), Hershey, PA: Information Science Publishing.

Guichon, N. (2009). Training Future Language Teachers to Develop Online Tutors' Competence Through Reflective Analysis. ReCALL, 21(2), 166-185.

Guichon, N., \& Hauck, M. (2011). Editorial: Teacher Education Research in CALL and CMC: More in Demand than Ever. ReCALL, 23(Special Issue 3), 187-199.

Hampel, R. (2009). Training Teachers for the Multimedia Age: Developing Teacher Expertise to Enhance Online Learner Interaction and Collaboration. Innovation in Language Learning and Teaching, 3(1), 35-50. 
Heitink, M., Voogt, J., Verplanken, L., van Braak, J., \& Fisser,P. (2016). Teacher's Professional Reasoning about their Pedagogical Use of Technology. Computers \& Education, 101(1), 70-83.

Helm, F. (2015). The practices and challenges of telecollaboration in higher education in Europe. Language Learning \& Technology, 19(2), 197-217.

Hockly, N. (2000). Modelling and 'cognitive apprenticeship' in teacher training. ELT Journal, $54(2), 118-125$.

Hofer, M., \& Grandgenett, N, (2012). TPACK Development in Teacher Education: A Longitudinal Study of Preservice Teachers in a Secondary M.A.Ed. Program. Journal of Research on Technology in Education, 45(1), 83-106.

Hofer, M. J., \& Owings-Swan, K. (2005). Digital moviemaking: The harmonization of technology, pedagogy and content. International Journal of Technology in Teaching and Learning, 1(2), 102-110.

INTEF (2014) Marco Común de Competencia Digital Docente. Borrador con propuestas de descriptores v1.0. Retrieved from http://blog.educalab.es/intef/2015/10/13/marco-comunde-competencia-digital-docente-version-en-ingles/

Jauregi, K. (2015). Task development for telecollaboration among youngsters. In J. Colpaert, A. Aerts, M. Oberhofer, \& M. Gutiérrez-Colón Plana (Eds), Proceedings of Task Design and Call: Seventeenth international CALL conference (pp. 312-321). Tarragona: Universitat Rovira i Virgili.HYPERLINK "http://blog.educalab.es/intef/2015/10/13/marco-comun-de-competenciadigital-docente-version-en-ingles/"

Jimoyiannis, A. (2010). Designing and implementing an integrated Technological Pedagogical Science Knowledge framework for science teachers' professional development, Computers \& Education, 55 (3), 1259-1269.

Kaye, A. (1989). Computer-mediated communication and distance education. In R. Mason and A. Kaye (Eds.) Mindweave: Communication, computers and distance education (pp. 3-21). New York: Pergamon Press.

Koehler, M. J., \& Mishra, P. (2005). What happens when teachers design educational technology? The development of technological pedagogical content knowledge. Journal of Educational Computing Research, 32(2), 131-152.

Koehler, M.J., \& Mishra, P. (2009). What is technological pedagogical content knowledge? Contemporary Issues in Technology and Teacher Education, 9 (1), 60- 70. 
Koehler, M., Mishra, P., \& Yahya, K. (2007). Tracing the development of teacher knowledge in a design seminar: Integrating content, pedagogy and technology. Computers \& Education, 49(3), 740-762.

Koehler, M., Greenhalgh, S., Rosenberg, J. \& Keenan, S. (2017). What the Tech is Going on with Teachers' Digital Teaching Portfolios? Using the TPACK Framework to Analyze Teachers' Technological Understanding. Journal of Technology and Teacher Education, 25(1), 31-59.

Koh, J.H.L., Chai, C.S., \& Tay, L.Y. (2014). TPACK-in-action: Unpacking the contextual influences of teachers' construction of technological pedagogical content knowledge (TPACK). Computers \& Education, 78, 20-29.

Long, M. (2015). Second language acquisition and task-based language teaching. Chichester: Wiley Blackwell.

McKenney, S., Kali, Y., Markauskaite, L., \& Voogt, J. (2015). Teacher design knowledge for technology enhanced learning: An Ecological framework for investigating assets and needs. Instructional science, 43(2), 181-202.

Marsh, D. (2002). CLIL/EMILE - The European dimension: Actions, trends and foresight potential. Jyväskylä, Finland: UniCOM, Continuing Education Centre, University of Jyväskylä. Retrieved from http://ec.europa.eu/education/languages/pdf/doc491 en.pdf

Meskill, C., Anthony, N., Hilliker-Van Strander, S., Tseng, C., \& You, J. (2006). Expertnovice teacher mentoring in language learning technology. In P. Hubbard and M. Levy (Eds.), Teacher education and CALL, (pp. 283-300). Amsterdam, The Netherlands: John Benjamins.

Mishra, P., \& Koehler, M. J. (2006). Technological Pedagogical Content Knowledge: A new framework for teacher knowledge. Teachers College Record. 108(6), 1017-1054.

Niess M. L., van Zee, E., \& Gillow-Wiles, H. (2010-11). Knowledge growth in teaching mathematics/science with spreadsheets: Moving PCK to TPACK through online professional development. Journal of Digital Learning in Teacher Education, 27(2), p. 42-52.

O'Dowd, R. (2013). The Competences of the telecollaborative teacher. The Language Learning Journal, DOI: 10.1080/ 09571736.2013.853374

O'Dowd, R., \& Waire, P. (2009). Critical issues in collaborative task design. Computer Assisted Language Learning, 22(2), 173-188. 
Olofson, M. W., Swallow, M. J., \& Neumann, M. D. (2016). TPACKing: A constructivist framing of TPACK to analyze teachers' construction of knowledge. Computers \& Education, 95, 188-201.

Palloff, R. M., \& Pratt, K. (2005). Collaborating online: Learning together in community. San Francisco, CA: Jossey-Bass.

Phillips, M. (2016). Re-contextualising TPACK: exploring teachers' (non-)use of digital technologies. Technology, Pedagogy and Education, 25(5), 555-571.

Polisca, P. (2011). Language learning and the raising of cultural awareness through Internet telephony: a case study. The Language Learning Journal, 39(3), 329- 343.

Pennock-Speck, B. (2013). Teaching Competences through ICTs in an English Degree Programme in a Spanish Setting. In Pérez Cañado, M. Competency-based language teaching in higher education (pp. 107-118). Dordrecht: Springer.

Roig, R., Mengual, S., \& Quinto, P. (2015). Conocimientos tecnológicos, pedagógicos y disciplinares del profesorado de Primaria [Primary Teachers' Technological, Pedagogical and Content Knowledge]. Comunicar, 45, 151-159. http://dx.doi.org/10.3916/C45-201516

Schmid, EC., \& Hegelheimer, V. (2014). Collaborative research projects in the technologyenhanced language classroom: pre-service and in-service teachers exchange knowledge about technology. ReCALL, 26 (3), 315-332.

Schmidt, D.A., Baran, E., Thompson, AD., Mishra, P., Koehler, M.J., \& Shin, TS. (2009). Technological pedagogical content knowledge (TPACK): The development and validation of an assessment instrument for preservice teachers. Journal of Research on Technology in Education, 42(2), 123-149.

Schwandt, T.A. (1997). Qualitative inquiry: A dictionary of terms. Thousand Oaks, CA: Sage.

Shulman, L. (1987). Knowledge and teaching: Foundations of the new reform. Harvard Educational Review, 57(1), 1-22.

Stemler, S. (2001). An Overview of Content Analysis. Practical Assessment. Research and Evaluation, 7 (17), 1 - 9. Available at http://pareonline.net/getvn.asp?v=7\&n=17

Teo, T. (2009). Modelling technology acceptance in education: a study of pre-service teachers. Computers \& Education, 52, 302-312.

Tondeur, J., Aesaert, K., Pynoo, B., van Braak, J., Fraeyman, N., \& Erstad, O. (2016a). Developing a validated instrument to measure preservice teachers' ICT competencies: 
Meeting the demands of the 21st century. British Journal of Educational Technology. doi:10.1111/bjet.12380

Tondeur, J., Pareja Roblin, N., Van Braak, J., Voogt, J., \& Prestridge, S. (2016b). Preparing beginning teachers for technology integration in education: Ready for take-off?

Technology, Pedagogy and Education,

http://dx.doi.org/10.1080/1475939X.2016.1193556HYPERLINK

"http://dx.doi.org/10.1080/1475939X.2016.1193556"

UNESCO (2011). UNESCO ICT Competency Framework for Teachers. Paris: UNESCO.

Vasileiou, V. N., \& Paraskeva, F. (2010). Teaching role-playing instruction in Second Life: An exploratory study. Journal of Information, Information Technology, and Organizations, 5, 25-50.

Vinagre, M. (2016). Developing Key Competences for Life-Long Learning through Virtual Collaboration: Teaching ICT in English as a Medium of Instruction. In C. Wang, \& L. Winstead, Handbook of Research on Foreign Language Education in the Digital Age (pp. 170-187). Hershey, PA: Information Science Reference (IGI Global).

Voogt, J., \& McKenney, S. (2016). TPACK in teacher education: are we preparing teachers to use technology for early literacy?, Technology, Pedagogy and Education, DOI: http://dx.doi.org/10.1080/1475939X.2016.1174730

Von Der Emde, S., Schneider, J., \& Kötter, M. (2001). Technically speaking: Transforming language learning through virtual learning environments (MOOs). Modern Language Journal, 85(2), 210-225.

Zaragoza-Ninet, MG., \& Clavel-Arroitia, B. (2010). Implementation of an innovation in education project in the degree of English studies at the University of Valencia. Porta Linguarum, 13, 103-118. 